\title{
Exploring Waste and Value in a Lean Context
}

\author{
Diana $_{\text {Chroneer }}^{1} \&$ Peter Wallstrom ${ }^{1}$ \\ ${ }^{1}$ Lulea University of Technology, Sweden \\ Correspondence: Diana Chroneer, Lulea University of Technology, Sweden. E-mail: diana.chroneer@ltu.se
}

Received: August 11, 2016

Accepted: September 6, 2016

Online Published: September 20, 2016

doi:10.5539/ijbm.v11n10p282

URL: http://dx.doi.org/10.5539/ijbm.v11n10p282

\begin{abstract}
The purpose of this paper is to take a critical, analytical approach to the concepts of waste and value in the lean literature and how the concepts are applied in organisations' lean efforts and the ambiguity surrounding the concept of value.

A review of the literature of lean was undertaken with a specific focus of the definitions of waste and value. In addition, it is illustrated how four case companies work with waste and value within a lean context. The literature review revealed that there have been significantly more frequent and exhaustive discussions of waste than of value. Waste is often related to the seven wastes, but value is rarely clearly defined. The cases show an exclusive focus on waste reduction, which we argue can result in a loss of value.

This paper provides a critical review of the relationship between waste and value and some of the consequences caused by the actions taken by companies regarding solely focusing on waste. This paper demonstrates the order winner and order qualifier dimensions should be regarded in the analysis of waste and value, and incorporated in the lean toolbox. In the lean research literature there is lack of discussion of the actual value for the customer. We argue that finding a special concept of value in the lean literature would be desirable, and elaborating on value as a specific tool in the lean toolbox, since the concept of 'waste' cannot replace the concept of 'value'.
\end{abstract}

Keywords: lean, value, order winner, order qualifier

\section{Introduction}

For some decades, Lean has influenced many aspects beyond how companies structure, operate and organise themselves (Samuel, Found, \& Williams, 2015). Research shows that lean has been applied in contexts outside large-scale manufacturing operations and production, such as in small to medium-sized manufacturing organisations (e.g. Enoch, 2013) and in a variety of industries ranging from construction (Gao \& Low, 2014) and process industry (Panwar, Nepal, Jain, \& Rathore, 2015) to healthcare (Kim, Spahlinger, Kin, \& Billi, 2006). As lean has progressed (Benders \& van Bijsterveld, 2000), both its definition and goal have developed to encompass, e.g. lean as a concept, a philosophy, an approach, a practice, a set of tools and techniques, a system etc. (Bhamu \& Sangwan, 2014). This confusion surrounding the meaning of lean has resulted in misguided efforts by companies using only the lean toolbox (Stone, 2012), e.g. Value Stream Mapping (VSM) and not understanding the reasons underlying a project failure (Scherrer-Rathje, Boyle, \& Deflorin, 2009). Therefore, this article aims to explore some of the consequences when a company solely regard lean as a toolbox, and proposes additional tools by investigating the relationship between waste and value.

Looking at the approaches and tools in lean, two main key concepts are value and waste (cf. Pavnaskar, Gershenson, \& Jambekar, 2003). Value is the starting point of lean and is defined by "the ultimate customer" (Womack \& Jones, 1996, p. 16). Womack and Jones (1996) also consider that value is created in the different parts of the production. Waste, on the contrary, is what does not add value to a product, process or a service (Naylor, Naim, \& Berry, 1999; Hines, Holweg, \& Rich, 2004). Thus creating value is a challenge today, since the product-life-cycles are shorter, customer demand for specialized products and services are stronger than when lean was first developed (Bernardes \& Hanna, 2009). Companies must understand customers' needs to improve customer satisfaction (Woodruff, 1997; Christopher \& Towill, 2001). Meeting customer demands and providing good value to customers is of great importance (Green, Lee, \& Kozman, 2010), i.e. to balance cost reductions and at the same time satisfy specific customer requirements (Pettersen, 2009; Panwar et al., 2015). But this is problematic, i.e. it is difficult to separate waste from value in activities (Browning \& Heath, 2009).

The lean research literature indicates some gaps that will guide this study: a lack of in-depth knowledge 
concerning the factors that cause companies to fail in their lean efforts (Marodin \& Saurin, 2013); the problem of separating waste from value activities (Browning \& Heath, 2009) and the complexity of value consisting of a multitude of dimensions (Sheth, Bruce, Newman, \& Gross, 1991; Hines et al., 2004; Oliver, Schab, \& Holweg, 2007). Also related to the lean literature, this paper explores (1) how waste and value are discussed and defined, specific the focus is on the ambiguity surrounding the concept of value. This ambiguity is also illustrated in four case studies within a lean context, in which the following questions were investigated: (2) how waste and value are applied in the organizations' industrial projects, and (3) consequences of when a company solely regard lean as a toolbox.

The paper is organized as follows; after introducing the research methodology, the basic concepts of waste and value are outlined and an overview of the existing research in the field is given. This overview touches on certain inter-linked streams of research such as studies on the roles played by order winners and order qualifiers in organizations' lean efforts. After the literature review, the results of the qualitative case study are presented. Finally the research results are discussed, revealing how the concepts of waste and, in particular, value are applied in the literature and by the studied companies.

\section{Literature Review}

Lean has its origins in the Toyota Production System (TPS). It was introduced by Krafcik (1988) and later popularized by Womack, Jones, and Roos (1990). The goals of lean are mainly emphasized as: removal of waste from the system, reducing cost/produce more with less, reducing lead time, etc. (Ohno, 1988; Liker, 2009; Bhamu \& Sangwan, 2014). The hallmarks of the lean thinking are thus identifying and eliminating waste (Browning \& Heath, 2009; Stone, 2012). However, if effective waste reduction is to be affiliated with lean then it is essential to understand how to pursue it (Browning \& Heath, 2009). Womack and Jones (1996, p. 19) state that lean thinking must start with a conscious attempt to precisely define value with specific customers.

An overview of how the lean literature have discussed and defined the concepts of waste and value is presented in Appendix A. The overview aims to identify tendencies in the definitions of waste and value. However, as the literature review revealed waste has a more explicit definition than value in the lean literature. For instance, waste is often related to the seven or eight wastes (or a variation) (Ohno, 1988; Womack \& Jones, 1996; Liker, 2009, pp. 50-51) while value is defined more implicit as depending on the customer's perspective (Arbulu, Tommelein, Walsh, \& Hershauer, 2003), customer satisfaction (Bhasin, 2008) or as "non-value" as things the customer does not perceive as added value (Moyano-Fuentes \& Sacristán-Díaz, 2012). Over the years, the definitions have not changed or developed in the lean literature. This is more elaborated on below.

\subsection{Waste}

Since 1990s, lean has grown in popularity and become a major paradigm in both research and practice (Stone, 2012). With its roots in TPS, lean emphasise waste reduction. While TPS focus on cost related waste issues, lean extend the concept to resources in general. The literature review revealed that the definition of waste has its origins in Ohno's (1988), Womack and Jones' (1996), seven wastes or some variant the seven wastes (e.g. Hines \& Rich, 1997; Arbulu et al., 2003; Chen \& Meng, 2010). This is especially true in analyses of papers published after the year 2000 (e.g. Ballard \& Howell, 2003; Chen \& Meng, 2010). According to Ohno (1988, p. 54) TPS is a method to: "thoroughly eliminate waste and enhance productivity".

In the literature, the seven wastes in TPS have influenced subsequent definitions, such as Liker's (2009, pp. 50-51) concept of wastes: overproduction, waiting, conveyance, over-processing, excess inventory, movement, defects, and unused employee creativity or expertise (the eighth waste). However, TPS is not only about the elimination of non-value adding activities but also aims to improve the quality of the product (Jasti \& Kodali, 2015). Another definition relates waste to value as "non-value" (e.g Braglia, Carmignani, \& Zammori, 2006; Moyano-Fuentes \& Sacristán-Díaz, 2012) and to "all efforts that do not add any value" (Arbulu, et al, 2003, p. 164). Waste can also be related to the customer opinions (e.g. Arbulu et al., 2003, Hines et al. 2004). But while lean in a majority of the literature have a similar view of what waste is, the quality movement lacks this precision and instead has a general definition of poor-quality-costs (Pettersen, 2009).

Viewing the concept of lean rationalization, it is a series of activities or solutions that are designed to eliminate waste, reduce time spent on non-value added operations, and increase productivity by improving quality, shortening lead times, reducing costs, and so on (Mason-Jones, Naylor, \& Towill, 2000). This has led to that lean production aims to eliminate all non-value adding activities. Its implementation therefore reduces waste in the production processes of goods and services, thereby decreasing costs (Browning \& Heath, 2009; Green et al., 2010). It is essential to recognize that processes can be non-value adding while being regarded as necessary to the operation (Naylor et al., 1999). 
Hence, the elimination of waste increases customer value by optimising the use of resources (Womack \& Jones, 1996; Narasimhan, Swink, \& Kim, 2006). One example is that a reduction in lead-time leads to an elimination of waste in the form of excess time (Christopher \& Towill, 2001). Further, the development of the value stream means the elimination of all waste, including time, to obtain a level schedule (Naylor et al., 1999). Also, various waste modes have been discussed in the literature. For example, Narasimhan et al. (2006) emphasize that it is important to recognize the different types of waste reduction, distinguishing between "obvious wastes" such as unneeded processes, (e.g. excessive setup times, unreliable machines, rework), and "less obvious" wastes that are associated with variability.

\subsection{Value}

A critical starting point for lean thinking is that value should be defined by the ultimate customer and meet: "the customer's needs at a specific price at a specific time" (Womack \& Jones, 1996, p. 16). But in the lean literature, the concept of value is often vaguely defined (cf. Arbulu et al., 2003; Braglia et al., 2006) and can be discussed related to value adding actives (Helmold, 2011). The customer is only willing to pay for products and goods, which are beneficial and add value to him. Non adding activities will not to be paid for and need to be radically erased (Helmold, 2011).

Value is also an intrinsically complex concept with both tangible and intangible attributes that stem from factors ranging from production processes to brand image (Hines et al., 2004; Oliver et al., 2007). Further, value is related to a multitude of dimensions (e.g. functional value, social value, emotional value, epistemic value, and conditional value) (Sheth et al., 1991). From 2000 and onwards, customer value is emphasized as a competitive priority (Moyano-Fuentes \& Sacristán-Díaz, 2012). Naylor et al. (1999) state that in order to understand value, the definition of a value-adding process must be expanded to encompass processes that are fundamentally non-value adding but necessary.

But looking beyond the lean literature, in the strategy and marketing literature, the concept of value is more thoroughly elaborated upon (e.g. Woodall, 2003). Bowman and Ambrosini (2010) suggest that value has two main components coupled to the transaction; use value, which is a subjective judgement of usefulness defined by the customer, and exchange value, the amount the buyer pays to the seller based on the perceived use value (Woodall, 2003). But Bowman and Ambrosini (2010) state that value creation is often confused with value capture. This can depend on that different disciplines focus on different beneficiaries of value ranging from customers, firms and society (Lepak, Smith, \& Taylor, 2007). Additional complications are that the value creation can be referred to both the content (e.g. regarding what is value/valuable, who values what, and where value resides) and the process of value creation (e.g. how value is generated). But in general, value creation relates to understanding customers' needs in terms of their prioritization of different objectives and the way they value quality in their products and services (Woodruff, 1997). For instance, value is discussed from the end customer's perspective in terms of specific product/service capabilities, price and availability, referring to Womack and Jones (1996). Value capture, on the other hand, is linked to the profits of a firm (Priem \& Butler, 2001) and concerns the proportion of the exchange value that a unit (e.g. department, firm. society) can retain from the customers' payments (Lepak et al., 2007; Priem, 2007).

Value can also be seen as dependent of its surroundings. For instance in production processes, value is a dynamic property that is more dependent on the output of a task than the intrinsic properties of the task itself (Browning \& Heath, 2009). But since value is an emergent property of a complex process that is more than the sum of its parts and that cannot be completely decomposed. The main dimensions of the total value of a product to the end user can be described in terms of service, quality, cost and lead-time (Naylor et al., 1999). However, Hines et al. (2004) do not consider these dimensions to be strategic aspects of value other than in mature industries.

Johansson, McHugh, Pendlebury, and Wheeler (1993) (in Mason-Jones et al., 2000) define value as the quotient of a set of dimensions. They propose the following model:

$$
\text { Value }=\frac{\text { Quality } \times \text { Service }}{\text { Cost } \times \text { Lead Time }}
$$

Also, Naylor et al. (1999) and Mason-Jones et al. (2000) use a quotient to define value because it is affected by both the effectiveness of the result and the efficiency of the process (Browning, 2003). Browning (2003) summarizes the work of Johansson et al. (1993) and other authors as follows:

$$
\text { Product Value } \propto \frac{\text { Benefits }}{\text { Costs }}
$$


The above definitions of value in terms of quotients show that value is a multidimensional quantity and that some of the relevant dimensions may be difficult to measure (Shah \& Ward, 2007). The expressions also imply independence between the different dimensions. This means that a change in one dimension will affect the value, but not the other dimensions.

Pawar, Beltagui, and Riedel (2009) argue that the aim of creating value is problematic because value is a relative concept with different meanings. To create and deliver value, the gap between operations and marketing must be closed. That is, it is necessary to combine the perspectives of the customer and the organisation, and their differing definitions of value. Also, value concerns several types of stakeholders, which might lead to conflicting value definitions. Näslund, Olsson, and Karlsson (2006) recommend relating value to the concept of utility, with a product's value being equal to the difference between its utility (e.g. the benefit it provides) and its cost (e.g. the price paid for it). This implies that the difference between value and customer value derives from the subjective nature of value analysis, with customer value being based on the customer's experience, i.e. the perceived value versus the perceived cost. More traditional approaches to value creation have been supplier-driven, i.e. largely based on the producer's view of value rather than the customer's, with the product taking precedence over its perception by the customer (Näslund, 2006).

As shown, the concept of value is multidimensional and therefore need to be clarified. Many authors have previous acknowledged the difficulties involved in defining value (e.g. Woodruff, 1997).

\section{Order Winners and Order Qualifiers-Analytical Framework}

In lean, various tools/techniques/methodologies exist, but they are standalone methods developed and used as such. This leads to that organisations practice lean principles as 'bits-and-pieces' instead of complete package across the organisation activities (Jasti \& Kodali, 2015). Bhamu and Sangwan (2014) emphasise that research is required to distinguish the standard tools/techniques/methodologies for lean manufacturing. Also, Wan and Chen (2008, p. 6569) state that "most of the existing lean tools (e.g. Kanban system, quick changeover, etc.) focus on 'how to become leaner' instead of 'how lean it is". Examples of categories that concern the level of leanness are: value stream mapping techniques, lean assessment tools, and lean metrics. For example, VSM has the main function to specifically identify opportunities for improvement and the elimination of waste (Hines \& Rich, 1997; Dal Forno, Pereira, Forcellini, \& Kipper, 2014). But, are there tools for handling value? As stated above, it remains challenging for producers to define value because of its relationship to customer satisfaction (Bhasin, 2008). Further, Koskela (2000) emphasizes the lack of procedures for effectively transforming value into product characteristics.

But in order to further extend the concept of value within lean, several authors (Mason-Jones et al., 2000; Christopher \& Towill, 2001) emphasize the importance of relating the ideas of 'order winners' and 'order qualifiers' to lean. Berry, Hill, and Klompmaker (1999) distinguish specifically between 'qualifying' and 'order winning' criteria. Order qualifiers are the criteria that a firm must meet for a customer to consider it as a possible supplier, while the order winners are the criteria that actually obtain orders. Some order qualifiers are more sensitive than others, and the firm will lose the order (and probably future orders too) if these are not met. Thus, these criteria are not static: they can change over time, they may be combined in some cases, and different markets and customers will have different preferences (Hill, 1995). Mason-Jones et al. (2000) discuss market qualifiers and market winners, asserting that cost is the market winner for the lean paradigm while quality and lead time are market qualifiers.

We argue that the concepts of order winners and order qualifiers can clarify value, and weight of different internal and external priorities in an organization. Cost, quality, dependability and flexibility have been proposed as key competitive priorities (Berry et al., 1999). Pawar et al. (2009) and Browning and Heath (2009) emphasize that a more holistic view needs to be taken, i.e. that value must be provided for all stakeholders (including customers, users, suppliers, employees, and shareholders).

However, an understanding of the customer's perception of value is only useful if this information can be operationalized. Ideally, such an understanding would enable a continuous evolution of operational processes in order to create and deliver value according to customers' needs (Näslund et al., 2006). da Silveira (2005) argue that an awareness of current operational requirements and capabilities is crucial, as is the introduction of initiatives to reinforce links between objectives, markets, products and other firm operations.

\section{Research Methodology}

The design of the study can be characterized as a multi-case study. The unit of analysis was four organizations' improvement work processes and how they considered waste and value when attempting to improve their 
processes in a lean context. The overall approach to lean in the individual organizations was not studied. A multiple case study is appropriate when knowledge exists concerning a phenomenon but also when there still exists a gap (Meredith, 1998). In general, case studies are suitable to build new theory but are lacking in the operation management research in general (Meredith, 1998; Barratt, Choi, \& Li, 2011). Eisenhardt (1989, p. 545) recommends using 4 to 10 cases to increase generalizability.

A myriad of literature related to theory and practices of lean is available in various publications. In this study, a literature review focused on how lean literature defines and describes waste and value. That is, how waste and value relate to different aspects of rationalization such as implementation of lean, how lean is assessed in organizations, use of tools as Value Stream Mapping (VSM). The articles that were of interest in the study focused on lean in relation to waste and value. Following online databases were applied: Scopus, Web of Science, Emerald Online, Science Direct, EBSCOhost and Taylor \& Francis publication portals. For the search criteria, the authors used the main concepts "lean", "waste", "value". Table 1 shows a schematic categorization of filtered articles and the selection process of the articles from the various online databases. A total of 30 articles were considered relevant for this present study.

Table 1. The search process in selected databases (compiled by the authors)

\begin{tabular}{|c|c|c|c|c|c|}
\hline Database (Note 1) & $\begin{array}{l}\text { First search criteria: } \\
\text { lean+value/ waste } \\
\text { Article/review }\end{array}$ & Number of articles & Further limitations & $\begin{array}{l}\text { Number of } \\
\text { findings }\end{array}$ & $\begin{array}{l}\text { Relevant } \\
\text { articles }\end{array}$ \\
\hline Scopus & $\begin{array}{l}\text { Abstract, keywords, title, } \\
\text { English }\end{array}$ & $\begin{array}{l}\text { value: } 2163 \\
\text { waste: } 802\end{array}$ & $\begin{array}{l}\text { Strings of lean and value } \\
\text { streams (Note 2) }\end{array}$ & $\begin{array}{l}\text { value: } 593 \\
\text { waste: } 483\end{array}$ & 9 \\
\hline Web of science & $\begin{array}{l}\text { Abstract, keywords, title, } \\
\text { English }\end{array}$ & $\begin{array}{l}\text { value: } 6807 \\
\text { waste: } 1309\end{array}$ & $\begin{array}{l}\text { Subject areas: } \\
\text { management and } \\
\text { engineering (Note 3) }\end{array}$ & $\begin{array}{l}\text { value: } 437 \\
\text { waste: } 150\end{array}$ & 5 \\
\hline EBSCOhost & All areas & $\begin{array}{l}\text { value: } 456 \\
\text { waste: } 540\end{array}$ & $\begin{array}{l}\text { Value as subject } \\
\text { Waste as subject }\end{array}$ & $\begin{array}{l}\text { value: } 374 \\
\text { waste: } 58\end{array}$ & 4 \\
\hline Emerald & $\begin{array}{l}\text { Lean: keywords } \\
\text { Value/waste: anywhere }\end{array}$ & $\begin{array}{l}\text { value: } 572 \\
\text { waste: } 483\end{array}$ & Value/waste as keywords & $\begin{array}{l}\text { value: } 42 \\
\text { waste: } 19\end{array}$ & 5 \\
\hline Science direct & $\begin{array}{l}\text { Abstract, keywords, title, } \\
\text { English }\end{array}$ & $\begin{array}{l}\text { value: } 2117 \\
\text { waste: } 387\end{array}$ & $\begin{array}{l}\text { Limited to journals (Note } \\
\text { 4) }\end{array}$ & $\begin{array}{l}\text { value: } 98 \\
\text { waste: } 23\end{array}$ & 5 \\
\hline Taylor \& Francis & All areas & $\begin{array}{l}\text { value: } 376 \\
\text { waste: } 106\end{array}$ & Lean as keyword & $\begin{array}{l}\text { value } 38 \\
\text { waste } 14\end{array}$ & 2 \\
\hline
\end{tabular}

Also, some of the reputed journals in the field of operations management that have published articles on research in lean production/manufacturing between the years 2010-2015 have been reviewed in order to view the late trends, see table 2. A total of 31 articles were found to be of relevance. The review indicated some gaps that have guided this study.

Table 2. The selected journals in the review (compiled by the authors)

\begin{tabular}{lll}
\hline Journals year 2010-2015 & $\begin{array}{l}\text { Number of papers } \\
\text { (criteria: lean+value) }\end{array}$ & Relevant articles \\
\hline Journal of Manufacturing systems & 76 & 0 \\
International Journal of Production Research, & 600 \\
Journal of Operations Management & 194 \\
International Journal of Operations and Production Management & 406 \\
International Journal of Production Economics & 489 & 6 \\
International Journal of Lean Thinking & 20 & 41 \\
\hline
\end{tabular}

As a second step, the articles were analysed with respect to their treatment of the concepts of waste and value, with a particular emphasis on the dimensionality of their approaches. Some of the reviewed articles elaborated on either one of the concepts or both are given as examples in Appendix A. Those that only mention the concepts of value and/or waste without further elaboration are indicated by a 'Yes' in the appropriate column; articles that did not mention these concepts are indicated by a 'No'. If the authors described or defined these concepts, their 
definitions are briefly summarized.

As a third step, four industrial projects were selected. The main data used in the cases consisted of comprised secondary data obtained from these four industrial projects with a specific focus on the results/outcomes of the projects and their conclusions. The projects were selected from ten projects that were conducted in parallel. The reason for choosing these four projects was that the purpose of each project was to rationalize and improve processes with respect to waste and value in a lean context. The rationalization took place in four different areas: (1) inventory management, (2) production, (3) administration, and (4) distribution (see additional information in Appendix B).

During the execution of the case study projects, the authors of this paper played a supportive role in the project teams, that is interacted with the team members, and had access to the collected data during the entire project time. This supportive role consisted of guidance and discussions. Each industrial project had a duration of 6 to 10 months. The data presented in each case represent the status of the corresponding project at the time of its realization. Detailed information on the four industrial projects, and the main findings, is provided in Appendix B.

The reports from the four industrial projects were analysed to determine how the recommended improvements were initiated and implemented in practice within each company. The analyses focused on following areas: the specified purposes of the projects, the consequences of pursuing the purposes, and aspects not considered by the organizations in the rationalization processes.

\section{Case Description}

This section presents a condensed set of results of the four industrial improvement projects that were examined in the context of lean with a specific focus on value and waste. The cases also illustrate some of the consequences of using lean as a toolbox. The four projects are referred to as the Inventory, Production, Administration, and Distribution cases. The descriptions are from a project view (operative perspective), not from a corporate management view, and give insights of the case companies' approaches to apply lean and some consequences thereof.

Each case description provides an overview of:

(1) The specific industrial project aim and the proposed solution,

(2) Consequences of the proposed solution in relation to possible order winners and order qualifiers of the business, and

(3) Identified waste and value.

For facts and information about the specific companies and collected data in each case, see Appendix B.

\subsection{The Inventory Project}

\subsubsection{Industrial Project Aim and proposed Solution}

The purpose of this industrial project was to identify and eliminate waste and thereby decrease costs by rationalizing the current inventory management and practices. The lack of standardized warehouse procedures had been identified as a source of waste by the management of the unit. Work processes, material handling and, the poor use of the Enterprise Resource Planning (ERP) system were identified as specific areas of waste.

According to the company's management, the rationalization would result in decreased costs and increased flexibility in staffing of the warehouses, i.e. enabling personnel to rotate between different warehouses. Unique to each warehouse was the handling of second hand parts which the personnel kept for instant repair instead of order and wait for new parts. There were no official records kept of these spare parts. The management had decided just to keep new spare parts since their ERP system required the input of standardized inventory data including purchasing price which could not be set to zero in the system.

\subsubsection{Consequences-Meeting Order-Winner/Qualifiers}

A critical factor for the customers (i.e. the order qualifier/winner in Hill's terminology) was in this case a possibility to obtain a quick repair, regardless of the age of the used replacement part. With the proposed ERP solution, however, a quick repair would not always be possible because some second hand parts would not be replaced with new spare parts in the standardized inventory. This led to a disagreement between the management and the service personnel. The customers regarded the use of second hand spare parts as a satisfactory solution since the customers' production down-time had been kept to a minimum over the years.

The management considered second-hand parts to be unreliable (despite the positive experience of using second 
hand equipment) and believed that customers had failed to understand this fact. The literature supports the view of the personnel and customers (Hameed et al., 2010) that the reliability is lower for new and old components and highest for components of intermediate age that has survived the burn-in phase. The failure rate of new equipment is much higher than for electrical components that survived the burn-in period (Brown, 2009, p. 165).

\subsubsection{Waste and Value}

The order winners and order qualifiers criteria differ between the company and the clients. The company management focused on cost, while their customers deemed lead time to be of greater importance. The customers' view therefore stressed the importance of service level. Waste in the form of a lack of standardization (i.e. inappropriate processing) was identified by the management. One consequence of the managers' suggestions was a reduction in availability of spare parts. This increased the risk of lengthy repair times that would harm the customers' production.

\subsection{The Production Project}

\subsubsection{Industrial Project Aim and Proposed Solution}

The company's purpose to initiate the improvement project was to increase the production volume without an increase of production resources. The company used a flow line production process involving several different workstations. A high degree of flexibility was required to accommodate different product variants. One workstation with long process time was therefore chosen in the project. The longest part of the process time was due to the drying operation and not the actual assembly operation. Most of the company's production passed through this workstation, and the long drying time was identified by the management as a waste. It was proposed that production volume could be increased by reducing the drying times without taking any compensatory measures.

\subsubsection{Consequences-Meeting Order-Winner/Qualifiers}

The company's major competitive advantage was their custom-made products with their numerous variations. But the complex production flows were regarded as a problem. The management's opinion was that the custom-made products caused significant waste for the company since resources could not be used as efficiently as when manufacturing standardized products. But a major benefit to the customers was that the custom-made products simplified the onsite production and increased speed of building activities. The customers' onsite production, planning and coordination of the workforce were less complex since the number of different professions needed were decreased with the prefabricated modules. It was important that the products were delivered on time and that the quality was consistent. Unreliable deliveries and the need to perform additional work onsite to address poor quality would lead to delays and extra costs for the customers. At the same time, the price of the product had to be lower than the cost of onsite production.

The shortening of the drying time in the production process resulted in an inferior product quality detected by the customers. Even if the correction work was paid by the case company, it also resulted in extra costs for the customers since the correction work delayed the customers' own production (longer lead time). The required correction work proved time consuming and complex due to limitations on work space and a lack of effective tools.

In the end, the company's attempt to eliminate waste was, in the project, replaced with a simulation of the whole production flow for different production layouts. Despite the initial waste study by the company, there was a lack of production data for deeper analysis. After months of data gathering, the simulation resulted in a proposed factory layout that could increase the efficiency of production without shortening the drying time. The suggested layout was based on current production practices, without any specific focus on waste.

\subsubsection{Waste and Value}

Two types of waste were identified by the management: waiting times and unnecessary inventory. Reducing the drying time reduced the lead time but also had adverse effects on product quality, causing unnecessary processing and rework at the customer site. The management focused on lead time to avoid investing in new production capacity. The customers' demand for product variation (historically offered by the company itself) and less utilization were regarded as a problem rather than a criterion that had to be fulfilled. The focus on decreasing lead time and cost overshadowed the quality dimension, which in this case should be regarded as an order qualifier. 


\subsection{Administration Case}

\subsubsection{Industrial Project Aim and Proposed Solution}

In this case, every year 200-300 production updates are ordered by the design department due to cause of the product development and changed customer demands. Each product update required a cost analysis to determine whether it could be accommodated within the firm's budget constraints. Also, each product update was analysed individually because they presented different technical challenges. The analyses were given the highest possible prioritizations, causing other activities across several departments to be postponed.

The production management believed that their current used standard cost for product changes did not reflect the real cost. The main concern of the management was to reduce the administration costs by reducing the number of production changes. So the management initiated an investigation to determine the real cost of a production change.

\subsubsection{Consequences-Meeting Order-Winner/Qualifiers}

In the project, it was suggested by a project member that a process mapping exercise of the administration process could be useful in the investigation and that it may be beneficial to standardize the product change analyses. This option was initially rejected by the management. However, the process mapping was investigated in parallel with the alternative to reduce the product change cost.

The change analyses proved to be $20 \%$ more costly than had been assumed previously. The process mapping exercise therefore indicated that it was not sensible to regard each production change as a unique event. The major problem was not the cost of the production updates analyses but the lack of a standardized processes and work flow between the involved departments. For the internal customer, the design department, it was important that the product development changes were implemented as soon as possible and that the production quality was consistent. The changes ordered from the engineering department might be to improve quality, but the information given to departments that managed the introduction was that it was customer requests that initiated the changes. The process mapping led to the suggestion that the frequent production updates should be done in clusters instead of-individually. This would postpone some of the changes but lower the administration cost of introduction.

\subsubsection{Waste and Value}

The emphasis in the project was to decrease the number of production changes, and not to increase the efficiency of the support process (by standardizing their work). The frequent production changes were regarded as a form of waste. It was highlighted in the project that the ad hoc cost analyses led to a form of inappropriate processing, so a standardization of the production analysis process was proposed. This in turn might have affected the internal customers-the design department-and it created waste in the form of 'waiting'. It was not clear whether the standardization caused any reduction in value for either internal or external customers. It might have affected the rate of improvement, but given the available data, it seems more likely that value was defined from an introspective engineering perspective. An overriding issue was that the advantages of the product changes, and their creation of value, were rarely obvious to the administration and production sectors.

\subsection{Distribution Case}

\subsubsection{Industrial Project Aim and Proposed Solution}

The company's purchasing department had identified its low utilization of trucks as a source of waste and argued that increasing their utilization would increase efficiency and reduce costs. A typical truck route was found to utilize between $20-40 \%$ of the vehicle's total capacity. The purchasing department came to the conclusion that the production sites should synchronize their orders to reduce the transportation costs. No estimation was made regarding the cost of synchronizing the transports to the different sites.

\subsubsection{Consequences-Meeting Order-Winner/Qualifiers}

Construction industry has generally an engineer-to-order supply with a complex network that is difficult to control because of the uncertainty (e.g. specification changes, onsite bottlenecks, reliability of suppliers) (Gosling et al., 2013). To reduce the uncertainty buffer activities can be used. The cost of the personnel waiting is generally more costly than the transports. Ballard and Howell (2003) stress the importance of having alternative activities available.

The practice of buffer activities required that the material and resources were available ahead of schedule. This is facilitated by the onsite managers being able to order material separately from each other. Furthermore, late changes in customer demand stressed the need for quick response times in the company's production and 
distribution operations. This demand for flexibility imposed significant constraints on the attempts to increase transport utilization. Support functions within the company had only limited access to the production status of the different construction sites.

Major benefits to the internal customers were that the individual and direct transports of material increased their onsite production flexibility and reduced the risk of unused labour due to lack of material.

\subsubsection{Waste and Value}

Transportation utilization was identified as a source of waste. However, a flexible distribution system was required to compensate for the uncertainties associated with on-site production. An efficient production site required a high service level. However, a synchronized distribution system would reduce the service level on the site, potentially leading to increased waiting times. That is, no materiel available on the site or inappropriate processing when activities had to be performed with inadequate resources.

\section{Analysis}

In the literature, waste tends to be more related to internal resource consumption, e.g. overproduction, transport, motion, waiting, and inventory, while value is either described in terms of the 'elimination of waste' (cf. Naylor et al., 1999; Moyano-Fuentes \& Sacristán-Díaz, 2012), or related to customer value in general terms (Arbulu et al., 2003), e.g. creation of value as defined by the customer (Kim et al., 2006). The analysis of the cases is based on the value definitions of Johansson et al. (1993). Thus, quality and service are taken as the numerators of the value equation while the sales price and lead time are taken as the denominators.

In all four industrial projects the companies' rationalizations focused on cost reductions and aimed to reduce waste in some way. Table 3 summarizes the projects initial purposes (stated by the company), the consequences of the different measures taken in the projects, and the indicated mismatch between the criteria that the projects had a focus on, and those criteria that the customers valued. The case studies indicated that the companies lacked a holistic view in their specific projects, i.e. the goal of the projects had other focuses than meeting customers' value. For instance, in the Inventory case, the project aimed to standardize the inventory processes, which lead to increased lead time for customers. This led to a mismatch between the project results; on one hand obtaining standardization, and on the other hand creating value to the customers, who valued short lead time.

Table 3. Summarize of the projects' aims and the customers' value (compiled by the authors)

\begin{tabular}{|c|c|c|c|c|}
\hline Cases & Inventory & Production & Administration & Distribution \\
\hline Industrial project aim & $\begin{array}{l}\text { Standardized } \\
\text { inventory } \\
\text { management }\end{array}$ & $\begin{array}{l}\text { Shorter throughput } \\
\text { time-in production }\end{array}$ & $\begin{array}{l}\text { Coordination } \\
\text { standardization } \\
\text { sub-processes }\end{array}$ & $\begin{array}{l}\text { Coordinated and joint } \\
\text { loading }\end{array}$ \\
\hline $\begin{array}{l}\text { Consequences } \\
\text { measures taken in the } \\
\text { projects }\end{array}$ & $\begin{array}{l}\text { Longer lead times to } \\
\text { customers }\end{array}$ & $\begin{array}{l}\text { Quality defects at } \\
\text { customers, expensive } \\
\text { re-work }\end{array}$ & $\begin{array}{l}\text { Decreased cost but longer lead } \\
\text { times for the product changes }\end{array}$ & $\begin{array}{l}\text { Longer lead times, } \\
\text { decreased production } \\
\text { flexibility }\end{array}$ \\
\hline $\begin{array}{l}\text { Mismatch project result } \\
\text { and customer value }\end{array}$ & $\begin{array}{l}\text { Standardization } \\
\text { Short lead time }\end{array}$ & $\begin{array}{l}\text { Short throughput time } \\
\text { vs Quality. }\end{array}$ & Cost vs. Short lead time & $\begin{array}{l}\text { Cost vs. Short lead time } \\
\text { and flexibility }\end{array}$ \\
\hline
\end{tabular}

The implications and the consequences of the identified waste reductions were not fully evaluated in the projects, i.e. important customer values (internal or external) were not considered. This is consistent with the findings of Browning (2003) and Hines et al. (2004), who identified a shift of focus in lean away from meeting customer needs towards pure waste elimination. In the projects, the value that needed to be provided to different stakeholders such as customers or users (e.g. Browning and Heat, 2009) were not considered. The case studies and the lean literature review show a tendency to focus on eliminating waste rather than reflecting on what creates value in different work processes, indicating a sub-optimization in the separate units in which the projects were carried out.

\subsection{Order Winner and Qualifier in the Cases}

The wastes that were dealt with in the cases above are summarized in Table 4, according to the seven wastes of the TPS: overproduction, waiting, transport, inappropriate processing, unnecessary inventory, unnecessary motion and defects (Hines \& Rich, 1997). The concept of value was not discussed, defined or highlighted in the projects.

The column 'Identified and adjusted waste' in Table 4, is based on the companies' perceptions of waste and their 
proposed or realized solutions. The 'created waste' column describes the new wastes created during the implementation of the project teams' waste reduction policies. The final column shows who was affected by the wastes identified in the first column (the term 'internal customers' refers to other divisions of the organisation than that responsible for the studied waste adjustment).

Table 4. Wastes identified in the case studies (compiled by the authors)

\begin{tabular}{|c|c|c|c|c|}
\hline Case & Identified and adjusted waste & Created waste & Affected value & Affecting \\
\hline Inventory & $\begin{array}{l}\text { Inappropriate processing Unnecessary } \\
\text { inventory }\end{array}$ & Waiting & $\begin{array}{l}\text { Lead time - order entry to delivery, } \\
\text { Cost }\end{array}$ & External customers \\
\hline Production & Waiting, Unnecessary inventory & $\begin{array}{l}\text { Inappropriate } \\
\text { processing Defects }\end{array}$ & $\begin{array}{l}\text { Quality - Fitness for use and } \\
\text { minimum variances }\end{array}$ & External customers \\
\hline Administration & Inappropriate processing & Waiting, & $\begin{array}{l}\text { Lead time - order entry to delivery, } \\
\text { response to market forces } \\
\text { Quality }\end{array}$ & $\begin{array}{l}\text { Internal and } \\
\text { external customers }\end{array}$ \\
\hline Distribution & Transport & $\begin{array}{l}\text { Inappropriate } \\
\text { processing Waiting }\end{array}$ & $\begin{array}{l}\text { Cost, Service - lost production } \\
\text { Flexibility }\end{array}$ & Internal customers \\
\hline
\end{tabular}

\subsection{Elaboration on the Concept of Value}

In all the cases, lean is applied as a set of tools in the projects, focusing on wastes (in accordance to Bhamu \& Sangwan, 2014). Table 4 reveals that the relationships are not only between waste and value but also between different dimensions of waste as well. An exclusive focus on waste can result in loss of value in other dimensions, as the case studies indicate. This can occur because value is difficult to quantify, as it is a relative concept with different meanings (Pawar et al., 2009). In the projects, order qualifiers such as quality, lead times and service levels were not discussed. But it is suggested that it is necessary to take a more holistic view when evaluating value and waste in order to enhance the understanding of what customer value in a product or service (cf. Bhasin \& Burcher, 2006). Managers must apply appropriate tools and strategies to provide customer value (Hines et al., 2004), but it is especially important to specify the conditions and to describe the intentions of the usage (Arlbjørn \& Freytag, 2013). However, customer value was not discussed in the projects in any of the four case studies. The four industrial projects focused on isolated units of the companies' operations in their attempts to make workflows more efficient. The companies' main objectives were to reduce specific wastes associated with individual operations, without analysing the impact of the resulting changes on other customers, internal or external, or whether the developed solution was suitable from a strategic point of view.

Similar to the cases, the literature review revealed that there are significantly more frequent and detailed discussions of waste than value. In some cases the definitions of these concepts are too vague or overly simplistic. Value is often mentioned in the lean literature but it is rarely clearly defined and do not exists in the lean tool box as for waste, e.g. in VSM (the seven or eight identified wastes). Eight of the articles identified in our review defined value specifically (e.g. Hines et al., 2004; Wan \& Chen, 2008). On the contrary, the definition of waste is often based on that provided by Ohno (1988) and in related references (e.g. Womack \& Jones, 1996), i.e. there is consensus regarding the concept of waste. The case studies presented in this work were internally oriented and generally disregarded the identification of customer values other than cost. This led to the conclusion that it is generally easier to identify waste than value in improvement work. The case studies also showed that when eliminating waste the focus of the improvement work is often on making sub-processes more efficient rather than evaluating the total value flow. One reason for the focus on waste elimination is that waste is easier to relate directly to resources than order qualifiers such as customers' demands for flexibility. That is, the required properties that a product or service must fulfil (the customers' needs) must be evaluated by the relevant stakeholder.' This implies that companies adhering too narrowly to lean principles will be disadvantaged in more customer-focused markets (Oliver et al., 2007). Therefore, we suggest that a full analysis of the main 'order winners' and 'qualifiers' of the products is critical in attempts make flows more effective (in accordance with Christopher and Towill, 2001), and in the attempts to eliminate waste. Companies increasingly require a high level of customized response to the differing needs of different customers (Purvis et al., 2014).

We agree with Hines et al., (2004), Oliver et al. (2007), and Pawar et al. (2009) that value is a relative and complex concept with different meanings consisting of both tangible and intangible attributes coming from the organization's development, production, and marketing activities. Therefore, we argue that the concepts of value and waste are often treated as a one-dimensional issue, both in the lean research literature and in the cases. 
Therefore, we propose, with a basis in the total value metrics of Naylor et al. (1999) and Mason-Jones et al. (2000), that the order winner and order qualifier dimensions should be regarded as sub-functions including both sub-dimensions of the major dimensions and the resources, and not only as the dimensions (Naylor et al., 1999); Quality (Q), Service (S), Cost (C), and Lead time (L). These dimensions are affected by a set of different contextual variables (e.g. type of infrastructure, organization, competence, uncertainty etc.) and resource variables $\left(r_{1} \ldots r_{n}\right)$, i.e. resources required for the dimensions as time, monetary means, and personnel. Though, the numbers of variables varies between the sub functions. The same resource variable can be present in several sub functions and influence the outcome of several dimensions. This is due to that different stakeholders might have different views of what value is and hence different value potentials are created depending on these views. The value potential can be viewed as a result of the function below.

$$
\text { Value potential }=\frac{\mathrm{Q}\left(\mathrm{q}_{1} \ldots \mathrm{q}_{\mathrm{n}},, \mathrm{r}_{1}, \ldots, \mathrm{r}_{\mathrm{n}}\right) \cdot \mathrm{S}\left(\mathrm{s}_{1} \ldots \mathrm{s}_{\mathrm{n}},, \mathrm{r}_{1}, \ldots, \mathrm{r}_{\mathrm{n}}\right)}{\mathrm{C}\left(\mathrm{c}_{1} \ldots \mathrm{c}_{\mathrm{n}},, \mathrm{r}_{1}, \ldots, \mathrm{r}_{\mathrm{n}}\right) \cdot \mathrm{L}\left(\mathrm{l}_{1} \ldots \mathrm{l}_{\mathrm{n}}, \mathrm{r}_{1}, \ldots, \mathrm{r}_{\mathrm{n}}\right)}
$$

In sum, several of the cases above indicate a classic mismatch between production processes and customer expectations, which lead to problems. The consequences of the projects also indicate that they are managed in isolation, not taken into consideration the lean perspective in which context the companies act in and have implemented.

\section{Conclusions}

It is recognized in the literature that organizations should embrace lean as a philosophy in order to succeed in their implementation of lean practices (Bhasin \& Burcher, 2006). This study shows however that applying the concept of waste and value in separate projects are difficult. Individual projects had their individual agenda and purpose with sub-optimization as a consequence, i.e. the companies' approaches to lean were not considered in the projects. This study shows that specifically analyzing value in the industrial projects in a lean context was neglected and not highlighted by the companies. This indicates that the lean philosophy and lean tools offer little support when analyzing value. However, this should not be equated that every lean improvement project will automatically fail, but if the concept of value is disregarded in making a process 'leaner', the outcome might be the same as in the studied projects.

It is questionable if value creation was part of the scheme in the cases. There were no improvements for the customers in the industrial projects, neither internal nor external. Instead, intentions were to decrease the cost for the isolated processes. In the production case their custom-made processes considered to be waste and it was emphasized to produce standardize products, and not to meet customers' need for flexibility. The distribution case illustrates a classic case of a single function (purchasing) looking at one metric (truck utilization) and then 'fixing' it without regarding its impact to other parts of the organization. There were no reflections on value creation or capturing processes. The notion of producing less with more implicates using less resource, which in turn implicates that waste is related to minimizing the used resources. Since waste is closer related to decreased costs, improved margins, and thus increased monetary value for the firm, it is more related to value capture than value creation.

We argue that being lean, and even though you work in specific projects in a lean context, you require an understanding of WHAT creates value, and the full effects of waste elimination. Critically, value must be understood as the properties of a product and/or service that fulfil the customer's requirements. Also, it is important to analyse both the work with and the consequences of the relationship between waste and value caused by the actions taken. This was not achieved in the case companies. They only considered the effects that specific actions had on sub-processes. Any rationalization work that attempts to proceed without a clear definition of value will be unable to effectively minimize waste.

Value is a multidimensional property with different meanings for different stakeholders. This is part of the explanation to why organizations do not always provide value for customers, but rather something that has the potential to become value. In order to develop potential value, however, an interaction with a customer is required. It is the customers' experience of the product or service that ultimately determines its actual value. Value is therefore a so-called "emergent property" in the production process, as Browning and Heath (2009) point out, and as such is difficult to measure when considering a sub-process in improvement work.

A reoccurring phenomenon in the lean research literature is the focus on what is not the value for the customer, not on the actual value for the customer. We argue that finding a special concept of value in the lean literature would be desirable, and elaborating on value as a specific tool in the lean toolbox, since the concept of 'waste' 
cannot replace the concept of 'value'. A product or a service produced with a minimum amount of waste but lacks fulfilling essential order winning and order qualifying proprieties will not generate value for the customer.

In sum, we state that in order to secure the value potential to customers (internal and external) organizations must identify and understand the relationships between variables of value and waste. This is not a trivial matter, as shown in the cases. Consequences of eliminating waste must be thoroughly evaluated. One suggestion in this paper is to apply a framework of order winning and order qualifying criteria in the analysis. Further research is needed to investigate and compare different methods used to identify value and waste, and their advantages and disadvantages. Thereby enable development of appropriate methods for identifying the real waste and develop the value potential.

\section{References}

Arbulu, R., Tommelein, I., Walsh, K., \& Hershauer, J. (2003). Value stream analysis of a reengineered construction supply chain. Building Research and Information, 31(2), 161-171. http://dx.doi.org/10.1080/09613210301993

Arlbjørn, S. J., \& Freytag, P. V. (2013). Evidence of lean: A review of international peer-reviewed journal articles. European Business Review, 25(2), 174-205. http://dx.doi.org/10.1108/09555341311302675

Ballard, G., \& Howell, G. (2003). Lean project management. Building Research and Information, 31(2), 119-133. http://dx.doi.org/10.1080/09613210301997

Barratt, M., Choi, T. Y., \& Li, M. (2011). Qualitative case studies in operations management: Trends, research outcomes, and future research implications. Journal of Operations Management, 29(4), 329-342. http://dx.doi.org/10.1016/j.jom.2010.06.002

Benders, J., \& Van Bijsterveld, M. (2000). Leaning on lean: The reception of a management fashion in Germany. New Technology, Work and Employment, 15(1), 50-64. http://dx.doi.org/10.1111/1468-005X.00064

Bernardes, E. S., \& Hanna, M. D. (2009). A theoretical review of flexibility, agility and responsiveness in the operations management literature: Toward a conceptual definition of customer responsiveness. International Journal of Operations and Production Management, 29(1), 30-53. http://dx.doi.org/10.1108/01443570910925352

Berry, W. L., Hill, T., \& Klompmaker, J. E. (1999). Aligning marketing and manufacturing strategies with the market. International Journal of Production Research, 37(16), 3599-3618. http://dx.doi.org/10.1080/002075499189943

Bhamu, J., \& Sangwan, K. S. (2014). Lean manufacturing: Literature review and research issues. International Journal of Operations and Production Management, 34(7), 876-940. http://dx.doi.org/10.1108/IJOPM-02-2012-0315

Bhasin, S. (2008). Lean and performance measurement. Journal of Manufacturing Technology Management, 19(5), 670-684. http://dx.doi.org/10.1108/17410380810877311

Bhasin, S., \& Burcher, P. (2006). Lean viewed as a philosophy. Journal of Manufacturing Technology Management, 17(1), 56-72. http://dx.doi.org/10.1108/17410380610639506

Bowman, C., \& Ambrosini, V. (2010). How value is created, captured and destroyed. European Business Review, 22(5), 479-495. http://dx.doi.org/10.1108/09555341011068903

Braglia, M., Carmignani, G. \& Zammori, F. (2006). A new value stream mapping approach for complex production systems. International Journal of Production Research, 44(18-19), 3929-3952. http://dx.doi.org/10.1080/00207540600690545

Brown, R. E. (2009). Electric Power Distribution Reliability (2nd ed.). CRC Press, Boca Raton, Florida.

Browning, T. R. (2003). On customer value and improvement in product development processes. System Engineering, 6(1), 49-61. http://dx.doi.org/10.1002/sys.10034

Browning, T. R., \& Heath, R. D. (2009). Reconceptualizing the effects of lean on production costs with evidence from the F-22 program. Journal of Operations Management, 27(1), 23-44. http://dx.doi.org/10.1016/j.jom.2008.03.009

Chen, L., \& Meng, B. (2010). The application of value stream mapping based lean production system. International Journal of Business and Management, 5(6), 203-209. http://dx.doi.org/10.5539/ijbm.v5n6p203

Christopher, M., \& Towill, D. (2001). An integrated model for the design of agile supply chains. International 
Journal of Physical Distribution and Logistics Management, 31(4), 235-246. http://dx.doi.org/10.1108/09600030110394914

Da Silveira, G. J. C. (2005). Market priorities, manufacturing configuration, and business performance: An empirical analysis of the order-winners framework. Journal of Operations Management, 23(6), 662-675. http://dx.doi.org/10.1016/j.jom.2005.01.005

Dal Forno, A. J., Pereira, F. A., Forcellini, F. A., \& Kipper, L. M. (2014). Value Stream Mapping: A study about the problems and challenges found in the literature from the past 15 years about application of Lean tools. The International Journal of Advanced Manufacturing Technology, 72(5-8), 779-790. http://dx.doi.org/10.1007/s00170-014-5712-z

Eisenhardt, K. M. (1989). Building theories from case study research. The Academy of Management Review, 14(4), 532-550. http://dx.doi.org/10.5465/AMR.1989.4308385

Enoch, O. (2013). Lean six sigma methodologies and organizational profitability: A review of manufacturing SMEs in Nigeria. American Journal of Industrial and Business Management, 3(6), 573-582. http://dx.doi.org/10.4236/ajibm.2013.36066

Gao, S., \& Low, S. P. (2014). The Toyota Way model: An alternative framework for lean construction. Total Quality Management and Business Excellence, 25(5-6), 664-682. http://dx.doi.org/10.1080/14783363.2013.820022

Gosling, J., Naim, M., \& Towill, D. (2013). Identifying and categorizing the sources of uncertainty in construction supply chains. Journal of Construction Engineering and Management, 139(1), 102-110. http://dx.doi.org/10.1061/(ASCE)CO.1943-7862.0000574

Green, J. C., Lee, J., \& Kozman, T. A. (2010). Managing lean manufacturing in material handling operations. International Journal of Production Research, 48(10), 2975-2993. http://dx.doi.org/10.1080/00207540902791819

Hameed, Z., Ahn, S. H., \& Cho, Y. M. (2010). Practical aspects of a condition monitoring system for a wind turbine with emphasis on its design, system architecture, testing and installation. Renewable Energy, 35(5), 879-894. http://dx.doi.org/10.1016/j.renene.2009.10.031

Helmold, M. (2011). Driving value in the upstream chain management through lean principles. International Journal of Lean Thinking, 2(2).

Hill, T. (1995). Manufacturing Strategy: Text and Cases. Macmillan Business, Basingstoke.

Hines, M., Holweg, M., \& Rich, N. (2004). Learning to evolve: A review of contemporary lean thinking. International Journal of Operations and Production Management, 24(10), 994-1011. http://dx.doi.org/10.1108/01443570410558049

Hines, P., \& Rich, N. (1997). The seven value stream mapping tools. International Journal of Operations and Production Management, 17(1), 46-64. http://dx.doi.org/10.1108/01443579710157989

Hines, P., Silvi, R., \& Bartolini, M. (2002). Demand chain management: An integrative approach in automotive $\begin{array}{lllll}\text { retailing. Journal of } & \text { Operations }\end{array}$ http://dx.doi.org/10.1016/S0272-6963(02)00036-0

Jasti, N. V. K., \& Kodali, R. (2015). Lean production: Literature review and trends. International Journal of Production Research, 53(3), 867-885. http://dx.doi.org/ 10.1080/00207543.2014.937508

Jayaram, J., Das, A., \& Nicolae, M. (2010). Looking beyond the obvious: Unraveling the Toyota production system. International Journal of Production Economics, 128(1), 280-291. http://dx.doi.org/10.1016/j.ijpe.2010.07.024

Johansson, H. J., McHugh, P., Pendlebury, A. J., \& Wheeler, W. A. (1993). Business process reeingineering: Breakpoint strategies for market dominance. John Wiley and Sons, Chichester.

Kim, C. S., Spahlinger, D. D., Kin, J. M., \& Billi, J. E. (2006). Lean health care: What can hospitals learn from a world-class automaker? Journal of Hospital Medicine, 1(3) 191-199. http://dx.doi.org/10.1002/jhm.68

Koskela, L. (2000). An exploration towards a production theory and its application to construction. $\mathrm{PhD}$ dissertation, Technical Research Centre of Finland, ESPOO 2000, VTT Publications.

Krafcik, J. F. (1988). Triumph of the lean production system. Sloan Management Review, 30(1), 41-52.

Lepak, D. P., Smith, K. G., \&Taylor, M. S. (2007). Value creation and value capture: A multilevel perspective. 
Academy of management review, 32(1), 180-194. http://dx.doi.org/10.5465/AMR.2007.23464011

Liker, J. K. (2009). The Toyota Way. Lean för världsklass. Liber AB, Malmö.

Marodin, G. A., \& Saurin, T. A. (2013). Implementing lean production systems: Research areas and opportunities for future studies. International Journal of Production Research, 51(22), 6663-6680. http://dx.doi.org/10.1080/00207543.2013.826831

Mason-Jones, R., Naylor, B., \& Towill, D. R. (2000). Engineering the leagile supply chain. International Journal of Agile Management Systems, 2(1), 54-61. http://dx.doi.org/10.1108/14654650010312606

Meredith, J. (1998). Building operations management theory through case and field research. Journal of Operations Management, 16(4), 441-454. http://dx.doi.org/10.1016/S0272-6963(98)00023-0

Moyano-Fuentes, J., \& Sacristán-Díaz, M. (2012). Learning on lean: A review of thinking and research. International Journal of Operations and Production Management, 32(5), 551-582. http://dx.doi.org/10.1108/01443571211226498

Narasimhan, R., Swink, M., \& Kim, S.W. (2006). Disentangling leanness and agility: An empirical investigation. Journal of Operation Management, 24(5), 440-457. http://dx.doi.org/10.1016/j.jom.2005.11.011

Näslund, D., Olsson, A., \& Karlsson, S. (2006). Operationalizing the concept of value: An action research-based model. The Learning Organization, 13(3), 300-332. http://dx.doi.org/10.1108/09696470610661135

Naylor, J. B., Naim, M. M., \& Berry, D. (1999). Leagility: Integrating the lean and agile manufacturing paradigms in the total supply chain. International Journal of Production Economics, 62(1-2), 107-118. http://dx.doi.org/10.1016/S0925-5273(98)00223-0

Nightingale, D. J., \& Mize, J. H. (2002). Development of a lean enterprise transformation maturity model. Information, Knowledge, Systems Management, 3(1), 15-30.

Ohno, T. (1988). Toyota Production System. Productivity Press: Portland, OR.

Oliver, N., Schab, L., \& Holweg, M. (2007). Lean principles and premium brands: Conflict or complement? International Journal of Production Research, 45(16), 3723-3739. http://dx.doi.org/10.1080/00207540701223600

Panwar, A., Nepal, B. P., Jain, R., \& Rathore, A. P. S. (2015). On the adoption of lean manufacturing principles in process industries. Production Planning \& Control, 26(7), 564-587. http://dx.doi.org/10.1080/09537287.2014.936532

Pavnaskar, S. J., Gershenson, J. K., \& Jambekar, A. B. (2003). Classification scheme for lean manufacturing tools. International Journal of Production Research, 41(13), 3075-3090. http://dx.doi.org/10.1080/0020754021000049817

Pawar, K. S., Beltagui, A., \& Riedel, J. C. K. H. (2009). The PSO triangle: Designing product, service and organisation to create value. International Journal of Operations and Production Management, 29(5), 468-493. http://dx.doi.org/10.1108/01443570910953595.

Pettersen, J. (2009). Defining lean production: Some conceptual and practical issues. The TQM Journal, 21(2), 127-142. http://dx.doi.org/10.1108/17542730910938137

Piercy, N., \& Rich, N. (2009). Lean transformation in the pure service environment: the case of the call service centre. International Journal of Operations and Production Management, 29(1), 54-76. http://dx.doi.org/10.1108/01443570910925361

Priem, R. L., \& Butler, J. E. (2001). Is the resource-based "view" a useful perspective for strategic management research? Academy of Management Review, 26(1), 22-40. http://dx.doi.org/10.5465/AMR.2001.4011928

Samuel, D., Found, P., \& Williams, S. J. (2015). How did the publication of the book The Machine That Changed The World change management thinking? Exploring 25 years of lean literature. International Journal of Operations \& Production Management, 35(10), 1386-1407. http://dx.doi.org/10.1108/IJOPM-12-2013-0555

Scherrer-Rathje, M., Boyle, T. A., \& Deflorin, P. (2009). Lean, take two! Reflections from the second attempt at lean implementation. Business Horizons, 52(1), 79-88. http://dx.doi.org/10.1016/j.bushor.2008.08.004

Shah, R., \& Ward, P. T. (2007). Defining and developing measures of lean production. Journal of Operations Management, 25(4), 785-805. http://dx.doi.org/10.1016/j.jom.2007.01.019 
Sheth, J. N., Bruce, I., Newman, B. I., \& Gross, B. L. (1991). Why we buy what we buy: A theory of consumption values. Journal of Business Research, 22, 159-170. http://dx.doi.org/10.1016/0148-2963(91)90050-8

Stone, K. B. (2012). Four decades of lean: A systematic literature review. International Journal of Lean Six Sigma, 3(2), 112-132. http://dx.doi.org/10.1108/20401461211243702

Wan, H., \& Chen, F. (2008). A leanness measure of manufacturing systems for quantifying impacts of lean initiatives. International Journal of Production Research, 46(23), 6567-6584. http://dx.doi.org/10.1080/00207540802230058

Womack, J. P., Jones, D. T., \& Roos, D. (1990). The machine that changed the world. New York: Rawson Associates.

Womack, J., \& Jones, D. T. (1996). Lean thinking: Banish waste and create wealth in your corporation. New York: Simon and Schuster.

Womack, J., \& Jones, D. T. (2003). Lean thinking. London: Simon and Schuster.

Woodall, T. (2003). Conceptualising 'value for the customer': An attributional, structural and dispositional analysis. Academy of Marketing Science Review, 12(1), 1-42.

Woodruff, R. B. (1997). Customer value: The next source for competitive advantage. Journal of the Academy of Marketing Science, 25(2), 39-53. http://dx.doi.org/10.1007/BF02894350

\section{Notes}

Note 1. Subject areas: Business management, Engineering, Social science, Economy.

Note 2. Keywords: Lean production, lean manufacturing, lean, lean construction, lean management, lean implementation, lean thinking, value stream mapping, value streams, value chain.

Note 3. Subject areas: Engineering manufacturing/ industrial/cicil/, business, management science, operations research management science.

Note 4. Journals: International Journal of Production Economics; Journal of Manufacturing Systems; Journal of Operations Management.

Appendix A. Literature Review

Mentions and definitions of waste and value in the Lean and agile research literature, and examples

\begin{tabular}{|c|c|c|}
\hline References & Value, defined/mentioned as & Waste (muda), defined/mentioned as \\
\hline Hines and Rich (1997) & $\begin{array}{l}\text { Value-adding processes in which a transformation takes } \\
\text { place }\end{array}$ & Seven wastes and the associated definition \\
\hline Hines et al (2002) & $\begin{array}{l}\text { Customer value and identifying value streams that add this } \\
\text { value }\end{array}$ & Yes \\
\hline $\begin{array}{l}\text { Nightingale and Mize } \\
(2002)\end{array}$ & Value to customers & Yes \\
\hline Arbulu et al. (2003) & From the customer's perspective. & $\begin{array}{l}\text { Eight wastes, as all efforts that do not add value } \\
\text { to the final product from the customer's point of } \\
\text { view }\end{array}$ \\
\hline $\begin{array}{l}\text { Ballard and Howell } \\
(2003)\end{array}$ & Yes & $\begin{array}{l}\text { Seven wastes, as being unnecessary for task } \\
\text { completion and value generation }\end{array}$ \\
\hline Pavnaskar et al (2003) & Yes & $\begin{array}{l}\text { Seven wastes, the use of any resources beyond } \\
\text { the minimum required to create value }\end{array}$ \\
\hline Hines et al. (2004) & $\begin{array}{l}\text { A wider and more complex range of tangible and intangible } \\
\text { attributes such as brand, image, environmental issues and } \\
\text { local production }\end{array}$ & $\begin{array}{l}\text { Wasted effort or time, the customer decides what } \\
\text { is waste }\end{array}$ \\
\hline $\begin{array}{l}\text { Bhasin and Burcher } \\
\text { (2006) }\end{array}$ & $\begin{array}{l}\text { Capability provided to the customer at the right time at an } \\
\text { appropriate price }\end{array}$ & Seven wastes \\
\hline Braglia et al. (2006) & By the end customer and discusses value-added time & Non-value-added costs \\
\hline Oliver et al. (2007) & $\begin{array}{l}\text { Multiple meanings depending on the customer, and is } \\
\text { determined by the balance between benefits and sacrifices }\end{array}$ & $\begin{array}{l}\text { Anything that adds cost but not value to a } \\
\text { product }\end{array}$ \\
\hline Shah and Ward (2007) & No & Exemplified in terms of excess inventory or \\
\hline
\end{tabular}




\begin{tabular}{|c|c|c|}
\hline & & excess capacity \\
\hline Bhasin (2008) & Customer satisfaction & No \\
\hline Wan and Chen (2008) & $\begin{array}{l}\text { Finished products, functionality, customer satisfaction } \\
\text { (quality, on-time delivery, service level, etc.) }\end{array}$ & Yes \\
\hline Piercy and Rich, (2009) & What the customers are prepared to pay for & Seven wastes \\
\hline Chen \& Meng, (2010) & Yes & Seven wastes \\
\hline Green et al. (2010) & Yes & $\begin{array}{l}\text { Benefit of waste reduction is improved } \\
\text { productivity or lower labour costs }\end{array}$ \\
\hline Jayaram et al. (2010) & No & Defects and long lead times \\
\hline $\begin{array}{l}\text { Moyano-Fuentes and } \\
\text { Sacristán-Díaz, (2012) }\end{array}$ & $\begin{array}{l}\text { "Non-value" as things the customer does not perceive as } \\
\text { added value }\end{array}$ & Equates waste to non-value \\
\hline
\end{tabular}

Appendix B. Case data

\begin{tabular}{|c|c|c|c|c|}
\hline \multirow[t]{2}{*}{ Case characteristics } & \multicolumn{4}{|l|}{ Case } \\
\hline & Inventory & Production & Administration & Distribution \\
\hline Size & Large & Medium & Large & Large \\
\hline Part of a Group & Yes & Yes & Yes & Yes \\
\hline $\begin{array}{l}\text { Employees (business } \\
\text { unit) }\end{array}$ & 2000 & $150-200$ & 1000 & 2000 \\
\hline $\begin{array}{l}\text { Customer (for the } \\
\text { production process in } \\
\text { focus) }\end{array}$ & Internal and external & External & Internal & Internal \\
\hline Degree of Lean & $\begin{array}{l}\text { Continuous lean work } \\
\text { (more than } 2 \text { years) }\end{array}$ & $\begin{array}{l}\text { Ongoing lean work } \\
\text { (less than two years) }\end{array}$ & $\begin{array}{l}\text { Continuous lean work } \\
\text { (more than } 5 \text { years) }\end{array}$ & $\begin{array}{l}\text { Initiated the previous } \\
\text { year, but not fully } \\
\text { implemented }\end{array}$ \\
\hline Company location & International & Local & International & International \\
\hline Competition & $\begin{array}{l}\text { International } \\
\text { Europe) }\end{array}$ & $\begin{array}{l}\text { International (Nordic } \\
\text { Countries) }\end{array}$ & Worldwide & Local \\
\hline Type of product & Maintenance service & Prefabricated modules & $\begin{array}{l}\text { Assembly } \\
\text { production }\end{array}$ & Constructions \\
\hline Orientation & Customer-specific & Customer-specific & Mass-customization & Customer-specific \\
\hline $\begin{array}{l}\text { Project focus } \\
\text { (company perspective) }\end{array}$ & $\begin{array}{l}\text { Decrease costs and } \\
\text { waste }\end{array}$ & $\begin{array}{l}\text { Decrease the } \\
\text { throughput time and } \\
\text { WIP }\end{array}$ & $\begin{array}{l}\text { Cost reduction in } \\
\text { support processes }\end{array}$ & $\begin{array}{l}\text { Decrease } \\
\text { transportation cost }\end{array}$ \\
\hline Information collected & $\begin{array}{l}6 \text { in-depth interviews, } \\
\text { a survey } \\
\text { respondents), }\end{array}$ & $\begin{array}{l}6 \text { interviews, } \\
\text { observation, } \\
\text { measurement } \\
\text { processes }\end{array}$ & $\begin{array}{l}14 \text { interviews, } \\
\text { historical data }\end{array}$ & $\begin{array}{l}\text { Historical data of } \\
\text { transportation and } \\
\text { contracts, continuous } \\
\text { dialogues with 5-10 } \\
\text { employees within one } \\
\text { department. }\end{array}$ \\
\hline
\end{tabular}

\section{Copyrights}

Copyright for this article is retained by the author(s), with first publication rights granted to the journal.

This is an open-access article distributed under the terms and conditions of the Creative Commons Attribution license (http://creativecommons.org/licenses/by/4.0/). 